\title{
PROPERTY VS. LIBERTY: PROCEDURAL LAW AND PRACTICE OF \\ FREEDOM TRIALS IN PORTUGAL AND BRAZIL
}

\section{SVEN KORZILIUS ${ }^{1}$}

\begin{abstract}
The article provides an overview of the historiographical debates on the relevance of law and courts for colonial slavery in the early modern, presenting several possible master narratives. Departing from the question about the legal sources used by the jurists of the early modern era producing "slave law in action", the article focuses on procedural law of the freedom trials, especially on the interim situation of the person whose status the trial was about. This aspect of the proceedings is fascinating, because here the tension between the two extreme positions of the parties (liberty vs. slavery/property) is discharged for the first time. A close look at the sources proves that the jurists sought to justify the possible solutions not only with the custom of the courts (stilus curiae), but that a variety of legal formants contributed to colonial slave law, notably the authority of the Roman model, which the article presents shortly in its development, and of certain medieval forms, like the summariissimum or the actio (or execeptio) spolii. Legal doctrine was frequently quoted. As a result, Brazilian colonial slavery did not occur in a legal vacuum, but proves to have been highly institutionalized, and many aspects of the civil law of slavery appear as a relatively conservative continuation of European practice, without visible innovations to the favor or the detriment of the unfree population.
\end{abstract}

Keywords: Law of slavery. Freedom trials. Interim measures.

\section{Propriedade vs. Liberdade. $O$ direito processual e a prática das ações de liberdade em Portugal e Brasil}

RESUMO: O artigo fornece uma visão geral dos debates historiográficos sobre a relevância do direito e dos tribunais para a escravidão moderna, colonial, e apresenta diversas master narratives possíveis. Partindo da pergunta sobre as fontes jurídicas usadas pelos juristas da idade moderna ao produzir a law in action da escravidão, o artigo focaliza no direito processual das ações de liberdade, particularmente na situção interina da pessoa, cujo status foi objeto da lide. Esse aspecto do processo é tão fascinante, porque aqui a tensão entre as duas posições extremas das partes (liberdade vs. escravidão/propriedade) foi descarregada pela primeira vez no litígio. Um olhar atento nas fontes prova que os juristas buscaram de justificar as soluções possíveis não somente com o stilus curiae (o costume do poder judiciário), mas que um grande número de formantes contribuiu ao direito da escravidão colonial, nomeadamente o modelo romano com sua grande autoridade, que o artigo apresenta brevemente no seu desenvolvimento, e certas formas medievais, como o summariissimum ou a actio (ou execeptio) spolii. A doutrina foi frequentemente citada. Em consequência, a escravidão no Brasil colonial não aconteceu num vácuo jurídico, mas revela-se como altamente institucionalizada, e muitos aspectos do direito civil da escravidão aparecem como uma continuação relativamente conservadora da herança europeia, sem grandes inovações em favor ou em detrimento da população escrava.

Palavras-chave: Direito da escravidão. Ações de liberdade. Medidas provisórias.

1 Doutor pela Universidade de Saabrücken, Alemanha. Pesquisador da Universidade de LudwigMaximilian, Munique, Alemanha. E-mail: sven.korzilius@gmail.com 


\section{Introduction}

In research on colonial slavery, we find the role played by law and courts very much debated. Whereas Tannenbaum (1946) and legal historians like Watson (1989) attribute an important influence to legal tradition, especially to Roman law in the case of Latin America ${ }^{2}$, experts of modern and Colonial history show some reluctance to admit or do even frankly negate any influence of the law on the slave societies of the New World ${ }^{3}$. Following this, their formation would have been dictated by economic imperatives only ${ }^{4}$, making them unique in world history of slavery ${ }^{5}$. We may structure these contrasting views by some possible master narratives. The first one would state that Iberian slave law, characterized as milder and more humane than the slave law of the Common Law tradition of Great Britain by authors like Tannenbaum ${ }^{6}$, was not applied in the colonies, because of the disdain of New World's master class, unwilling to accept any restraints of exploitation. Therefore, state institutions like courts would have had no function in the regulation of the master-slave-relationship ("protective law" - "oppressive masters"). A second way to tell the story does not at all consider benign the peninsula's slave law as practiced at the end of the Middle Ages, but rather sees it as a slave law already fitting very well the interests of a master class, the reason why the colonizers used it to form their new slave societies. This master narrative fits the image of the role of courts in the shaping of (colonial) slave societies as one of mainly imposing cruel punishments for often minor offences of slaves and freedmen, thus forming just another instrument of repression in the hands of the master class. This was a seamless continuation of the repressive and often inhuman practices on plantations. This narrative continues by argues that improvements achieved by slaves led to a derogation of archaic European slave law, forming a new, colonial and customary slave law ("oppressive law" and "oppressive masters" - "resistant slaves").

\footnotetext{
2 Among comparative studies inspired by Tannenbaum are Elkins (1959), Klein (1967), Degler (1971); Conrad (1994), Scott (2005), Cooper et al. (2000), Landers (1999), Ingersoll (1999), Din (1999), as well as the literature quoted in Bergard (2007).

${ }^{3}$ Cf. Osterhammel (2009), who applies the metaphor of Roman law as an empty seashell, which could not give any form to modern slavery.

${ }^{4}$ Figueira/Mendes (1977, esp. p. 33).

5 Cf. Blackburn $(1996,3)$ : "radically new in character compared with prior forms of slavery"; Osterhammel (2009, 28), Elsenhals (2007).

${ }^{6}$ Today, this view is quite rightly relativated.
} 
In opposition to both of these possible narratives, a third one is possible - statig, that Portuguese slave law was applied in Brazil without extensive changes in favor or of the masters or of the slaves ("conservative slave law"). In accordance to a fourth master narrative, European slave law did not reach the colonies at all ("legal vacuum"). The legally nearly unrestricted power of the master class is interpreted as only limited by the slaves' successful negotiations and resistance. In a frequently quoted article, Cunha (1985) develops the thesis of the absence of state institutions and of metropolitan slave law in master-slave relationships, stressing the existence of customary law instead, developed in direct negotiations between the two parties or groups. As to the Brazilian context, we can link these interpretations to certain phases of historiography. Slaves were interpreted as relatively passive victims of plantation capitalism, without any rights, by authors who number among the Escola Sociológica Paulista ${ }^{7}$ (which fits best to the first master narrative). A younger generation of scholars, emerging since the 1980s, stresses the quality of slaves as historical subjects instead. In this context, the idea of slaves conquering rights becomes crucial ${ }^{8}$ (this fits with the second or fourth master narrative). The still inspiring leading questions these debates provoke are: did a Brazilian slave law existe? And to what extent did it differ from Portuguese slave law?

The younger historiography began to pay attention to the civil branch of colonial courts and its mechanisms to define status. A person kept as a slave might have learned about a manumission given to him and sought a court to enforce it, or claimed a right to be freed following from a corresponding promise or last will. Or maybe a person living for years as a freedperson found herself discovered as a fugitive slave, and was suddenly called back into slavery, or liberty was revoked because of "ingratitude" or because of not paying the contracted installments of the price for freedom. Investigating such cases, commonly referred to as freedom suits (but better, because it is more neutral, and reflects more precisely both possible directions: status suits), began with studies like the pioneering one of Grinberg (1994). Brazilian historians interpreted freedom suits as a relatively late development and mostly related them closely to the abolitionist movement of the nineteenth century

\footnotetext{
${ }^{7}$ Gonçalves (2006, p. 25), cites as examples Bastide/Fernandes (1959), Costa (1988), Cardoso (1962).

${ }^{8}$ See, for example, the interpretation of manumissions as strategies of resistance by Paiva (1995).
} 


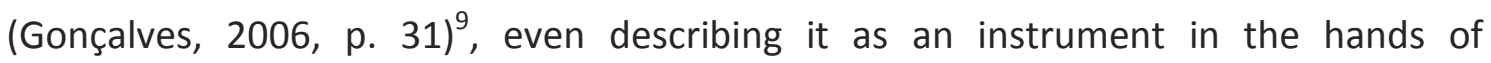
abolitionists. Not surprisingly, the origins of the Brazilian freedom trial are sometimes dated not before the second half of the eighteenth century (Grinberg, 1994, p. 24$25)^{10}$. One of the first authors paying attention to the eighteenth century is Diório (2007). More recent studies reveal the existence of such cases already during the colonial era and broaden the scope of investigation to the Portuguese Atlantic, like the exemplary study of Pinheiro (2013).

Although most of the freedom trials levied at the Portuguese National Archive (Torre de Tombo, ANTT) only date back to the era of Pombal and represent the dexterous implementation of the legislation against the importation of slaves and finally against slavery as such by the slaves and their supporters (Pinheiro, 2013, p. 1718), we have to go further and consider that already Portugal's medieval and early modern courts knew such claims of the "Moorish" unfree emanating from the "Reconquista". Unfortunately sources prior to the eighteenth century are extremely scarce, but there exist some traces ${ }^{11}$. In Évora, in the year 1582, Grácia "mourisca" recorded in the books of the notary public a sentence stating her freedom, obtained against a local capitular, her arrogated owner ${ }^{12}$. But blacks do appear as parties quite early. In the year 1569, at Évora as well, Brás Fernandes recorded a power of attorney to defend his freedom judicially against Beatriz Figueira, his ostensible mistress, basing his argumentation on a manumission given by an ex-owner ${ }^{13}$. Freedom suits do also already appear in collections of decisions, for example the case of Pero Simões, resident in Vila Verde, against Beatriz Ribeira, in the year 1582, in the collection organized by Belchior Febo (1625, Arest. 35). An emblematic trajectory of a slave in the Portuguese empire of the late seventeenth century is the one of Adu. Hailing from the kingdom of Meknes, he became the slave of Gonçalo da Costa de Alcáçova Carneiro de Meneses, governor of Angola during the years 1691 to 1694. Returning to Lisbon after

\footnotetext{
${ }^{9}$ For manumissions see for example Bertin (2004), Eisenberg (1987), Nishido (1993), Gonçalves (2000). For freedom trials see Chalhoub (1990), Azevedo (2003); Gurgel (2004).

${ }^{10}$ See also Silva (2007, p. 141).

${ }^{11}$ To compensate a little bit this lack of sources I would like to quote works on Valencia in the 15th and Granada in the $16^{\text {th }}$ centuries. Blumenthal (2009, p. 210-217) detected dozens of files of "demandes de libertad" between 1425 and 1520. Martín Casares (1995, p. 209) speaks of "pleitos por [...] libertad".

${ }^{12}$ Fonseca (2002,182 ff.), quoting ADE, FN, Évora, Liv. 260, f. 77 v, 23.1.1587.

${ }^{13}$ The record mentions a „causa e demanda que ele quer(ia) mover contra Beatriz Figueira, sua senhora que foi, sobre sua alforria, porquanto o quer(ia) fazer cativo deixando-o seu senhor forro" (ADE, FN, Évora, Livro 199, f. 59, in Fonseca (2002).
} 
the termination of his mandate, the governor promised to free Adu formally immediately after arrival at the capital. Alas! Adu's owner died during the passage. Reaching Lisbon the freed slave did not hesitate to seek out the court to secure his prospected freedom. The court thought it sufficient, that some witnesses had heard the promise given on the ship, and declared Adu free ${ }^{14}$. This simple example should be a sufficient introduction to the subject of the freedom (or better: status) trial.

Since Pinheiro (2013), the argument for the irrelevance of the courts for colonial slavery lost ground ${ }^{15}$. Even if she does not claim to have used a "formal comparative method" (Pinheiro, 2013, p. 18), the sources used by Pinheiro at least implicitly also show that the legal bases and their application did not differ essentially between Portugal and Brazil. But the legal comparison may be further developed. The present article concentrates only on one small but crucial detail: preliminary injunctions about the factual situation of the person whose status was controversial during the proceedings, since the clash appearing in these suits, between the defense of property rights on the one side, and the right to freedom on the opposite one, was not only a question of substantive law, but expressed itself quite often fiercely during the proceedings ${ }^{16}$. Whereas the party whose status was questioned sought to experience the trial like a free person, the second party wanted to see that first one treated like chattel until the final sentence, as certain extrajudicial ${ }^{17}$ and procedural manoeuvres reveal. This battle over the interim situation in many cases consumed the energies of parties and their lawyers for months. The present article investigates the instruments the jurisprudence developed to balance the opponents interests and while favoring one not completely putting into risk the other. Whereas enjoying unrestrained freedom during the trial the "slave" could use it for flight, being kept as a

\footnotetext{
${ }^{14}$ Arquivo Nacional Torre de Tombo (ANTT), Feitos Findos (FF), Fundo Geral, Letra A, maço 1200, caixa 2403, processo 14.

${ }^{15}$ Her explicit statement on p. 95 deserves full approval ("a Justiça foi sim um recurso aplicado em confrontos dessa natureza e [...] seu acionamento coloca em dúvida a dispensa da arena jurídica na resolução de tais conflitos e a aceitação do pleno exercício da vontade senhorial e patronal"); also her conclusions, p. 95, that especially the masters did use the courts as means to protect their peculiar property, the slaves.

${ }^{16}$ These two aspects could have been seperated more sharply by Pinheiro.

${ }^{17}$ A very blatant case of unlawful interference is reported by Blumenthal (2009, p. 213): Pere, owner of Nicholau, a slave, but factually living in freedom, to work and earn money to buy his freedom, once tried to drag Nicholau, "literally, back into his service." Pere "had grabbed him by the hair, tearing out a large clump of it", but Nicholau could run away and find "shelter in a friend's house".
} 
"thing" in the hands of his "owner", the latter could render impossible any procedural action of the former. As the measures to be taken were provisional only, we may not presume that the problem was closely regulated and without doubt the judges enjoyed a wide margin of discretion, but we would be misguided, if we did not seek for legal bases at all. So what was the legal framework for such interim measures?

Some concluding remarks of Pinheiro form our point of departure. She claims that there were no specific determinations about the freedom trials in the Ordinances (Ordenações) or in other Portuguese laws. Most important would have been customary law ("usos") and the "stilus" ("estilo") of the courts (Pinheiro, 2013, p. 281). This observation is incomplete to a certain extent. It is true, that the civil proceedings law of modern Portugal (including the special rules for freedom trials) was only fragmentarily codified in the Ordinances, so that the courts had to use the subsidiary sources mentioned in the famous passage of book II, chapter 9 of the Afonsine Ordinances ${ }^{18}$. Lawyers, however, had more liberty to cite the Ordinances, Roman Law and Canon Law directly, but also national and international legal doctrine, as well as codifications of other kingdoms, like the Siete Partidas of Spain. It is remiss not to mention these numerous legal references, or formants $\left(\right.$ Sacco, 1991) ${ }^{19}$, because in fact as a whole they form the early modern law of Portugal and Brazil ${ }^{20}$ as a part of the much larger legal family of the early modern Civil Law, the "ius commune"21. Among the subsidiary sources mentioned by the Ordinances, special attention has to be paid to Roman Law, because the modern freedom trial quite obviously was anything but new. As one of the most important slave societies in the history of mankind, the Romans experienced status lawsuit ${ }^{22}$ in the directions [rei vindicatio] in servitutem or

\footnotetext{
${ }^{18}$ In the following ranking order: the stilus, the customary law, the Roman Law ("Leis Imperiais"), but the Canon Law ("Santos Cânones"), if the application of Roman Law would lead to sin. Accursius was declared the authoritative glossator, and if no solution could be found in his works, Bartolus should be consulted. As is well known, the Manueline Ordinances meant a certain opening, because the communis opinio now could be prevail over Accursius or Bartolus.

${ }^{19}$ Speaking of formants, a very short but striking extract of a freedom trial of $15^{\text {th }}$ century Valencia (Blumenthal, 2009, p. 213) shall be quoted: The freedom of the slave in that special case could be legally based on "disposiciones de drets canonich e civil e de furs del present regne".

${ }^{20}$ Pinheiro (2013, p. 137-150) describes the proceedings quite well, but there are only scarce quotations of contemporary doctrine, legal sources etc. to back this description.

${ }^{21}$ In this short article I may not enter into the debate about the concept "ius commune".

${ }^{22}$ In the Digest, the entire title 12 of book 40 is dedicated to them, and in the Justinian Code the entire title 16 of book 7 (cf. also 4.9 of the Theodosian Code).
} 
[rei vindicatio] in libertatem ${ }^{23}$. There are sufficient hints in the sources that a certain range of interim measures about this conflict during the trial were also developed as early as the Roman republic, or maybe even when Rome was still a kingdom. Studies on the modern status suit mostly neglect this inheritance ${ }^{24}$. However, a profound comparison of the legal semantics of ancient and modern slavery is a crucial argument to question the thesis of the uniqueness of modern slavery and to stress a certain cultural unity between ancient and modern slavery ${ }^{25}$. One leading question of this article therefore is to detect to what extent the legal writings of modern lawyers show their knowledge of the existence of the freedom suit in ancient Rome and how they used it to base their solutions. Here, I do not enter into the "big" debates about continuity or rupture between the ancient and the modern world (Schiavone, 2002) ${ }^{26}$ and about the proper way (referring to hermeneutical theory) to interpret the use of Roman law in the early modern world (reception, transfer ${ }^{27}$, (legal) transplant or cultural translation? $)^{28}$, but I hope my initial comparative remarks will foster further, necessary dialogue with romanists and ancient historians.

${ }^{23}$ Correctly streching the importance to differ between the two directions, for the modern freedom trial, Pinheiro $(2013,91)$.

${ }^{24}$ Even though the written pleadings in the records of Mariana and Lisbon are full of them, Pinheiro for example does not quote one single prescription of the Corpus luris Civilis, if we are not mistaken.

${ }^{25}$ See the committed call for a more profound comparison of ancient and modern slavery by Dal Lago/Katsari (2008).

${ }^{26}$ But I do take an unequivocal stand on the side of those who stress continuities rather than ruptures, namely because of the medieval development of slave law and slavery, as investigated by Nehlsen (1972), who unfortunately concentrates on delicts commited by slaves and therefore does not touch our subject, the status suits, Verlinden (1955) and many others, and especially the phenomenon we may call "Mediterranean Colonialism" (Feldbauer et al., 2005). I do reject, on the contrary, a rupture in the $15^{\text {th }}$ century (between medieval and modern slavery). A little bit clumsy on this matter is Delacampagne (2002). He divides the book in three big parts, and lets the first part end with medieval century. This insinuates an important rupture between medieval Mediterranean and modern Atlantic slavery. Nevertheless, at the very first pages of the second part, Delacampagne stresses the continuity.

${ }^{27}$ Gaudemet (1976) prefers that concept to reception.

${ }^{28}$ On these debates see Duve (2012). However, Genzmer's critique (quoted by Duve, 2012, p. 49) is not convincing. Genzmer (1953) still uses "reception" without any critical remarks, Genzmer (1958) already shows a certain distance, but only by using quotation marks. Genzmer (1961) wants to reject the concept becausee of its vastness and ambiguity. We may ask, if transplant or translation are less ambiguous and used in a more uniform way by authors working in the field... The concepts proposed by Genzmer (1961, p. 144) to replace "reception" ("infiltration" or "penetration") are worse, because their tendency to ignore the agency of the historical subjects is even stronger. Wieacker (1967, p. 132) defends the concept of reception partially against Genzmer, and also Sellert (1998) and Willoweit (2002) continue to use it. More recently, Giaro (2007) in a very nuanced article shows the deficits of the concept of transfer and therefore does not to abandon the concept of reception aas well. Maybe we have to use all the four of the concepts cumulatively, to explain the long and complex transfer of Roman law to the colonies and Native populations. 
Interim injunctions in status trails - a brief outline of the development in Ancient Rome

The first difficulty, when we ask, if the ancient Roman status trial could have served as a model for the modern one, is that the Roman status trial did not exist. Rather, as is the case with civil procedure law as a whole, its historical development passed through several changes during the more than 1,200 years of Roman history ${ }^{29}$. In the era of the Republic, the person claimed as slave or claiming to be free, in terms of the capacity to sue and to be sued, was treated more like a piece of property, a thing (res), to be vindicated ${ }^{30}$, and consequently not able to act as a litigant. This role had to be played by the adsertor libertatis who acted as if he would "revindicate" the "slave" ${ }^{31}$. In such a rei vindicatio, already in the age of the legis actio sacramento in $\mathrm{rem}^{32}$ we have to separate carefully two legal concepts - that of ownership and that of (quasi- ${ }^{33}$ )possession - the first one describing the legal situation, the second one the factual situation ${ }^{34}$. In a preliminary decision, called vindicias dicere, the Roman magistrate decided who could enjoy "possession" of the item in dispute during the proceedings (Kaser/Hackl, 1996, p. 99) ${ }^{35}$. The sources tell us about a particularity of the freedom trial: the judge had to decide this preliminary situation always secundum libertatem, in favor of the party claiming liberty ${ }^{36}$. What this meant in practice, is not

\footnotetext{
${ }^{29}$ A short introduction gives Metzger (2013); see also Peixoto (2013, p. 14-23).

${ }^{30}$ Franciosi (1961, p. 231): "oggetto di processo". The ritual of the rei vindicatio at that age is described in the Institutes of Gaius $(4,16)$. Both parties had to touch the claimed object with a bar (vindicta/festuca) and to speak a certain formula. After that, the magistrate asked both parties to leave the object ("mittite ambo rem (hominem)").

${ }^{31}$ The formula of a "normal“ rei vindicatio was modificated: The adsertor had to pronounce "liberum esse", and the "owner" could pronounce, without modification, "meum esse" (Indra, 2011, p. 38).

32 Existent at least since the early Republic (about BC 500), but very probably already during the age of the kings (Kaser/Hackl, 1996, 92). On the freedom trial in the form of a legis actio see Sciortino (2010, ch. II).

${ }^{33}$ It was the famous medieval jurist Baldus de Ubaldis, in his commentary on the Justinian Code (3.4.3), who denoted freedom and slavery as quasi-possession.

${ }^{34}$ For the modern Portuguese and Brazilian freedom trials this is very well demonstrated by Pinheiro (2013), see the title of the first chapter of her thesis: "A posse e o usufruto da liberdade"). However, maybe the term "social condition" ("condição social") should have been avoided to denominate this factual situation, because for a lot of sociologists, legal status is one factor for the social condition (the social condition of a slave who lives on his/her own is not the same as of a free person who lives on her own).

35 The Roman jurist Gaius tells us in the Institutes (4.16), that this means, that the judge "interim aliquem possessorem constituebat".

${ }^{36}$ We know this because of Livius, Ab urbe condita, III, 47, 56, 58, narrating the famous freedom trial of Virginia (Nicolau, 1933, p. 179-198; Franciosi, 1961, chapter 6, pp. 197 ff.); see also D. 1.2.2.24.
} 
quite clear. Kaser/Hackl (1996, p. 101 and 103), Kaser/Knütel/Lohsse $(2017,104)$ and Indra (2011, p. 38 and 88 ) hold that the person the trial was about could really live as free $^{37}$, others assert that the adsertor could keep the "slave" safe ${ }^{38}$, deciding, how much liberty of movement he would dare to concede her/him ${ }^{39}$. In any case of a flight of his protégé, the adsertor or some bailsmen ${ }^{40}$ were held responsible and had to pay the value to the owner, if the latter won the case ${ }^{41}$. The actio in rem per sponsionem, which substituted (or modified) the legis actio sacramento in rem (Kaser/Hackl, 1996, p. 105), despite the abolition of the vindicias dicere maybe did not mean any radical alteration as to the question of the interim situation of the "slave" ${ }^{42}$. The process of agere per formulas ${ }^{43}$ probably began during the Mid-Republic, and during the Late Republic rolled back the two older forms of civil procedure. The parties became more clearly defined as plaintiff and defendant ${ }^{44}$. The cautiones continued being satisdationes by suitable bailsmen (sponsores idonei) ${ }^{45}$. During classical times ${ }^{46}$, the situation seems to have been altered in a way even more favorable to the pretendent

\footnotetext{
${ }^{37}$ See also D. 40.12.24.pr. and D. 40.12.25.2.

${ }^{38}$ Nicolau (1933, p. 128) speaks of a "véritable droit de garde sur la personne du prétendu esclave et sur ses biens", and (p. 140) of a "certain pouvoir de l'adsertor sur le prétendu esclave", called custodia. The interim freedom of a slave was "une liberté [...] surveillé". Franciosi (1961, p. 232) agrees: "Le vindiciae secundum libertatem attribuiscono la custodia dell'individuo a colui che ne asserisce la libertà"; see also Franciosi (1961, p.258): The judge attributed possession to the adsertor (attribuzione del possesso all' adsertor libertatis").

${ }^{39}$ Sciortino remains vague to the question to what extent the adsertor libertatis could restrain the liberty of the "slave" (Sciortino, 2010, p. 156).

${ }^{40}$ Praedes litis et vindiciarum, see Degeneffe (2006).

${ }^{41}$ Especially in a procedure extra ordinem, the adsertor had to deposit a bail, securing the claimed owner against a loss of his potential slave (Nicolau, 1933, p. 116).

${ }^{42}$ At least the cautio pro praede was a satisdatio, i. e. a stipulatio substantiated by a bailsman (sponsor), Gaius, Inst. 4, 89 and 94, Kaser/Hackl (1996, p. 106, note 108). It is controversial, if the status trial was possible at all in this form in both directions (Scortino, p. 2010, ch. III).

${ }^{43}$ See Sciortino (2010, ch. III), who states that the freedom trial was dealt with in this form since the early Principate. The details about the possible form of the freedom trial in that age are highly controversial. Nicolau (1933, p. 145-147) holds the view that in freedom trials never was proceeded per sponsionem. Sciortino's main thesis is that neither the agere per formulam, nor the agere per sponsionem was possible for a trial with the direction "in libertatem". In that case, a praeiudicium an liber sit would have been developed early. But this controversy is not relevant for the main question of the present article, the interim measures. Unfortunately, Sciortino (2010) hardly deals with them.

${ }^{44}$ D. 40.12.7.5. This made an ordinatio iudicii or litis ordinatio necessary in cases where it was dubious, if the person whose status was controversial in fact lived as free or as unfree at the beginning of the trial.

45 Kaser/Hackl (1996, p. 279). Gaius, Inst. 4.91, may be interpreted in the way that the stipulatio pro praede and the cautio iudicatum solvi do not differ essentially. During classical times, the adsertor had to provide bail directly, not by a bailsman (Indra, 2011, p. 168 and 230-231). Also concerning the agere per formulas it is controversial, if it is was possible in both directions (Sciortino, 2010, ch. III).

${ }^{46}$ That is more or less between AD 30 and AD 235.
} 
of freedom, who was maybe put into interim liberty directly, without custody by his adsertor (Franciosi, 1961, p. 231-232), but the "owner" did in no way possess the "slave" for the duration of the proceedings ${ }^{47}$. During the postclassical Empire we observe more transformations. By the reform of the year $342 \mathrm{~A}$. D. (abolition of the agere per formulas) the cognitio extra ordinem (which is structurally already much closer to the civil proceedings of our days) became the standard form of civil proceedings in the Roman empire. The tendency went to conserve the factual situation, such as it existed at the beginning of the proceedings, during the same. If a person claimed in libertatem, she was conserved as a slave until the final sentence ${ }^{48}$, if someone claimed a person in servitutem, the latter one might continue to live as free until the final sentence, but had to provide bail (fideiussor). If the "slave" was not able to provide bail, it was possible to use the cautio iuratoria (swear an oath), but if the "slave" abused the situation to depart and did not appear before court for one year after being summoned, the absentee was automatically declared the slave of the claimant $^{49}$. The last important reform happened under the reign of Justinian - the adsertor was abolished, and the person whose status the trial was about gained the capacity to sue and to be sued (for the freedom trial as such). This very brief overview reveals no linear development. The material of several chronological layers, in the form it survived in the Corpus luris Civilis, was full of lacunae, interpolations and contradictions. But we may identify some crucial elements, like the decision of the judge as to the roles of the parties and the respective factual situation of the "slave", the bail someone had to put to enable her/him to stay in factual freedom during the proceedings, or the possibility of custody in the case of not getting a proper (idoneus) bailsman.

\section{The development in modern "ius commune", especially in Portugal}

\footnotetext{
${ }^{47}$ Dig. 40.12.25.2 [Gaius]: „Tantum de possessione videbimus, cum ipsum post litem ordinatam desinat dominus possidere [...]."

48 In this sense we may interpret Dig. 41.2.3.10 [Paulus, Libro 54 ad edictum]: „si ex possessione servitutis in libertatem reclamaverit et liberale iudicium imploraverit, nihilo minus in possessione mea est [...]". May it be, as Nicolau $(1933,251)$ suspects, interpolated or not (Paulus worked after AD 200).

${ }^{49}$ See Justinian Code (Cod.) 7.17.1.2 (de adsertione tollenda). It seems, that in the era of Justinian there did exist a bail to warrant the object of the litigation only in excepctional cases (Kaser/Hackl, 1996, 576). The fideiussor of Cod. 7.17.1.2 would have the function of a mere cautio iudicio sisti.
} 
The medieval glossators, postglossators (commentators), the following generations of the mos italicus and mos gallicus and, last but not least, the canonists worked on this Roman heritage and shaped what is often called the Roman-canon procedural law (Trusen, 1962; Nehlsen-von Stryk, 1991; Litewski, 1999; Nörr, 2012), which constituted the central legal basis of the freedom suit during the Middle Ages (for lack of sources unfortunately nearly unknown, at least concerning Portugal) and the Early Modern Age. In proceedings about chattels or real estate, the magistrate could make a preliminary decision of the possessory situation during the proceedings ${ }^{50}$ called summariissimum or mandantum de manutenendo ${ }^{51}$ from the fifteenth century onwards (Coing, 1985, p. 286-287). It is controversial among modern authors, as to mandatum de manutenendo was a late medieval creation ${ }^{52}$ or if it was the mere application of the Roman prescriptions (Lobão, 1867, ch. X, § 166). However one of the references used to underpin this institute was D. 40.12.7.5 (Postio, 1646, Observation IV, n. 1) - a regulation on the preparation of a status trial, more exactly on the definition of the role of the claimant and the defendant taken from the comment of Ulpian (who lived around the year 200 A.D.) on the edictum perpetuum (of the year 130 AD). The important editor of a Portuguese collection of decisions, Macedo (1699, decis. 52), who, like Postio, quotes D. 40.12.7.5 explicitly, explains that it would be the same procedure called vindiciarum in the antiquity. Despite its brevity, this hint is fascinating because it shows that Macedo cares about the historical development of the institute, and that in his opinion the proceedings in their passage from the Republican age of the legis actiones to the cognitio of the Late Empire did not suffer major changes as to this detail. It is no surprise that the summariissimum was very frequently used in the modern freedom trial ${ }^{53}$, especially by persons who feared to be

50 See Postio (1646) and Menochio (1687). Unfortunately neither Litewski (1999), nor Nörr (2012) provide indications about functionally comparable measures in the older Roman-canon proceedings.

${ }^{51}$ Translating manutenção we have to be very careful. "Maintenance", which is really the same word, juridically can be absolutely misleading! The civil law practice of maintaining someone in the possession of something, the institute of the mandatum de manutenendo of continental ius commune, has nothing in common with the common law's "writ of maintenance".

52 Against the idea that the summariisimmum could be detected in Roman law already: Sarmiento (1616, 128), Böhmer (1762, p. 637).

${ }^{53}$ One example is the case of Manuel Rodrigues of the year 1806, quoted by Pinheiro (2013, p. 62). In her chapter on petitions to be maintained in liberty, Pinheiro (p. 151-165) does not reveal its origin, legal basis, or the doctrine quoted by the jurists in their written pleadings; a clear distinction between summariissimum and possessorium ordinarium is missing. Even the contemporary jurists did not always distinguish neatly, according to Lobão, (1867, p. 120), between the isolated summarissimum 
caught by arrogated owners. If such a person was already caught, and the owner at the same time had started an action against her liberty, the proceedings could be interrupted by an exceptio spolii ${ }^{54}$ (in Portuguese: esbulho), a device developed by canonist procedural law during the Middle Ages ${ }^{55}$, until the person was set free again. In such a situation, the difficulty for the judge often was to decide if the person deprived of her factual liberty was to be considered simply a fugitive, without any right to enjoy freedom, or if the situation of her "possession of liberty" was so firm, that it was worth being protected.

In the worst case, during the modern age the factual slave claiming his freedom had to continue under the authority of his master (Barbosa, 1712, headword Servus), a solution corresponding to the probable situation of the Late Roman Empire $^{56}$. According to the sixteenth century Spanish jurist Otálora (1570, p. 151-152), the decision to put the "slave" in interim liberty (Otálora, 1570, p. 152, quotes C.7.16.14 and D. 40.12.24 for that solution), or to let him full under the authority of the presumed owner, depended on the quality of the title ("titulu[s] vel instrumentum servitutis") the owner was able to present. In some cases, the "slaves" who had remain under the authority of their masters could at least request the "owner" to guarantee, the individual would not be maltreated (cautio de non offendendo ${ }^{57}$ ) or removed to a distant place (Otálora, 1570, p. 152 ${ }^{58}$; see cases below). Practice, "stilus", had developed a further mitigation of the slaves' situation - while litigating, the slave had to serve during three days of the week only, having three days off to be able to attend to his claim ${ }^{59}$. We see the property claim and the freedom claim both halfway

and the one combined with the main action. A petition to be maintained in liberty could be filed in three procedural situations: As the main request of an ordinary possessory action, as the main request of an isolated summary action, or as a request for an interime measure.

54 During my current research I also have found freedom trials in the form of an actio spolii, but as this article is about interim measures only, I do not consider them here.

${ }^{55}$ The canonists used the model of the interdict unde vi, cf. Goecke (1858) and Ruffini (1889).

${ }^{56}$ Cf. at footnote 48, above. In ANTT FF FG maço R 375, Rita Thereza (mulher preta) ./. Jozé Ferreira Mendes (von 1767), fol. 59 the lawyer justifies this with the circumstance, that the owner in return had to maintain the "slave". As legal authority he quotes Fragoso (1737, p. 622), where Fragoso allegates D. 41.1.19.

${ }^{57}$ The cautio de non offendendo was frequently used in marital disputes. A short and not too demanding introduction offers the Summa of Savelli (1748, p. 239-242).

${ }^{58}$ The Oydores [judges] order, "que el señor da fianças de dexar seguir al sieruo su causa, y no le trasportar, ni maltratar \&c."

59 Febo (1625, arest. 35): "Somente he obrigado seu senhor a darlhe tempo para yr a requerer sua justiça âs audiencias, \& casa dos officiaes de justiça, \& por estyllo se lhe dão tres dias na semana 
satisfied $^{60}$. However, sometimes, this did not go far enough as to the "slaves". They often stated their fear of being hidden in private dungeons, transported to distant places or abused, and requested to be taken away from the house of their owners with the aim of being put into safe custody at a third person's place ${ }^{61}$. Unfortunately, the requests generally do not quote legal references explicitly ${ }^{62}$. A general argument to justify the measure was the "favor libertatis". Some lawyers saw this solution also as a product of stilus ${ }^{63}$, some quote Ord. Fil. $3.78 .5^{64}$. Such a custodianship was not uncommon during litigations concerning moveable objects (Lobão, 1867, ch. XII), especially as a variation of the summariissimum (Postio, 1646, obs. LXXV), as well as in the case of marital conflicts ${ }^{65}$. But, as we see by the fact that it was very often the slave to request it, the custody cannot be seen as a means to protect the property rights of the "owner" only, but again, like the three days off, as a reconciliation of the

[...]."Arouca (1742, adnotat. ad. lib. 1 tt. $^{\circ} 6$ et his qui sunt sui L. $\S 1$ n. $\left.{ }^{\circ} 25\right):$ "Et praxis observat dies a domino convento tres in hebdomada servo largiendi ut liti pro sua libertate intentata possit assistire". Sometimes, the jugdes already defined exactly, which of the days should be conceded to the slave. See the case ANTT FF FG maço J 725, cx. 1644 (Joanna Maria de Santa Anna ./. Agostinho da Silva Hofmann, von 1802). It seems that there is no precedent in Roman law, and also the modern doctrine outside of Portugal seems to ignore this solution.

${ }^{60}$ To my great pleasure I see now, during a rereading of Blumenthal (2009, p. 215), that this was very similar in Valencia. In one case (see below) though, the days off were only two.

${ }^{61}$ For the fifteenth century Valencia Blumenthal $(2009$, p. 215) reports that when „filing a demand for liberty, slaves turned themselves over into the protective custody of the governor. They would then be placed either in the city's prison or in a designated safe house. Nevertheless, in many instances, at a master's or mistress' urging, the court would release the slave back into their owner's custody. The court would only do so, however, upon receipt of a sworn promise from the master (or mistress) that they would neither physically harm the slave nor take him or her outside the city limits. In this way, the court worked to ensure the slaves could not be intimidated or bullied into withdrawing their claims." In one important example (p. 213, note 72), the mistress had to swear "de no maltractar aquella axi com si no fos sclava e aço sub pena de docents florins [...]" and to permit "que dos dies de la setmana ço es lo dimarts e lo divendres en lo apres dinar una hora en cascu dels dits dies que aquella puxa venir parlar e comunicar ab lo procurador e advocat per la present causa." The struggles and their solutions are amazingly similar to our own findings in Portugal and Brazil! But see also the case of Russian slave Anna (Blumenthal 2009, p. 215-216), whose owner did violate such an oath, whipping her cruelly and transporting her out of the city.

${ }^{62}$ Maybe this is the case in Blumenthal's (2009) sources as well, because Blumenthal does not quote a single legal allegation in the passages on the interim solutions.

${ }^{63}$ ANTT FF FG maço J 3022, Irmandade de Nossa Senhora do Rosario (Graça) ./. João Antonio Pereira (of the year 1810), fol. 1: „depozito do Estillo”; ANTT FF FG letra J, maço J 2734, Irmandade de Nossa Senhora do Rosario (Graça) por cabeça de Thomazia Maria ./. Luis Romão Lopes, fol. 4 ("he do estillo"). ANTT FF FG maço J 3015, Irmandade de Jesus Maria José (Carmo) ./. Lourenço da Costa Piedade (von 1830): „Antes de se propôr a competente acção de liberdade de qualq[ue]r preta ou parda conservada em escravidão neste Reino contra o preceito da ley, he practica proceder-se no depozito $[\ldots])^{\prime \prime}$.

${ }^{64}$ Historical Archive "Casa Setecentista", Mariana, Minas Gerais [AHCSM], Autos Cíveis [AC] 2, 274, 6728, fol. 3 shall be quoted here, although it is colonial and not from the metropole.

${ }^{65}$ Postio (1646, Obs. XLIII, § 4) speaks of a "depositum Mulieris". 
property interests with the interests of the "slave". The depositing had to be in an "honest and secure house". It was no exception, that one party doubted the qualities of a depositary proposed by the adversary. A slave's request to be kept safe was not very different of that of an abused woman, who could ask to be taken away from her husband during the proceedings of a divorce (Postio, 1646, obs. XLIII). Quite often, in practice, safe custody meant a high degree of preliminary freedom, because depositaries who did not fear flight, let the slaves move quite unrestrained ${ }^{66}$, instead of keeping them "under lock and key". The depositary in such a case turned himself much more into a bailsman, a function which required that he was propertied, especially with real estate. In some cases, a person claimed as slave could stay in freedom during the proceedings only when providing bail ${ }^{67}$. This can be interpreted as an application of Ord. Fil. 3.31.pr and 2, a prescription that incorporated the idea that bail served as cautio iudicium sisti and to warrant the value of the object. In some cases, the litigants tried to provide only a cautio iuratoria, as mentioned in the Justinian Code 7.17.1.2. There is no clear line of jurisprudence in the question of providing bail.

In Lisbon, where blacks during the seventeenth and eighteenth centuries formed about ten percent of the population, members of their well organized lay brotherhoods (the best known being the one of Our Lady of the Rosary) processed the streets collecting money to help unfree members to buy their freedom, and assisted their members in freedom suits, frequently as nominal plaintiffs of representative actions, or at the least in paying lawyers' fees. In 1767, the lawyer of the black slave Rita Thereza made a request that she should be deposited based on the fear that her assumed owner could block her right to continue the freedom trial against him ${ }^{68}$. The court conceded to the interim measure, but now the owner entered with an appeal, alleging that the whole matter was initiated by the depositary whose intention would be to fraudulently employ the services of the slave. He only wanted to grant the slave the usual three days off. It would be a small triumph for every slave, were it sufficient

\footnotetext{
${ }^{66}$ To the disappointment of the "owners", who got to know about their deposited "slaves" strolling around.

${ }^{67}$ See, especially for the status trial, Cod. 7.17.1.2.

${ }^{68}$ He could do something, "a fim de não poder uzar do Dir[ei]to da Reclamação de liberdade, que contra elle tem intentado." (ANTT FF FG letra R, maço 375).
} 
to bring suit against his master, to get rid of the duty to serve him (at least for a while), and in consequence it would hardly exist any Master not confronted with freedom trials $^{69}$. The attorney of "slave" Elias Ximines in 1767 went less far. He requested to have Elias deposited, or, in case his alleged owner desired to continue to be served by Elias, at least a cautio de non offendendo ${ }^{70}$. Such a cautio was also solicited in the case of the Brotherhood of the Rosary (Salvador da Mata) against Dr. Manuel Francisco de Carvalho, in behalf of the slave José Narciso da Cunha ${ }^{71}$. The lawyer quotes Cortiada $(1665, \text { p. } 95 \text { [decision 66, §§ 11-14]) })^{72}$, but also German authors, namely the dissertatio "De agris desertis" (Stryk (praes.)/Fuchs (resp.) ${ }^{73}, 1698$, chapter VII, $\S 49^{74}$ ) and Brunnemann (1683, p. 23 [on D. 1.6.2] $)^{75}$.

69 "Alias por certo que não seria de pequeno triumpho para os Escravos, se apenas demandassem seus $\mathrm{S}[\mathrm{e}] \mathrm{n}[\mathrm{ho}$ ]res pella liber[da]de, e logo se reputassem livres, e p[ar]a effeito de já mais os servirem, poiz estou certo que a praticar-se este absurdo, não haveria S[enho]r algum sem letigio movido pelo seu escravo, porque, como não pagão custas sempre ao menos interassavão a izenção do trabalho."

70 "[O] Supp[lica]do caucione de non offendendo, cazo q[ue] queira uzar das obras do servo pendente a lide sobre a liberdade" (ANTT FF FG maço J 3616).

${ }^{71}$ The trial is of the year 1777, ANTT FF FG maço J 2941. The quotations are at fol. 166. Not only had the "owner" to provide bail, but the judge threatened him with a fine of 200,000 Reis and ten years of exile in Angola (fol. 257) in case maltreated the litigant. This exile in my opinion is quite clearly inspired by D. 1.6.2, a passage of the Digest mentioning the exile of a certain Umbricia for maltreatment of her slave: "Divus etiam Hadrianus Umbriciam quandam matronam in quinquennium relegavit, quod ex levissimis causis ancillas atrocissime tractasset." In English (translation: Scott): "The Divine Hadrian also, banished for five years a certain matron named Umbricia, because she had treated her female slaves with atrocious cruelty for very trivial reasons." See also the solicitation of an exile for the case of the maltreatment of a slave in ANTT FF FG maço J 3775, Irmandade de Nossa Senhora do Rosario (Santa Marinha) ./. Capitão Jozé Lopes da Silva (1773).

72 Cortiada follows the opinion, that a slave who fled to a church because he feared to be maltreated (or had already suffered maltreatment) by the owner ("si servus propter domini saevitiam [...] ad Ecclesiam confugit"), had to be restituted to the latter ("dominus est restitutendus"), but only "recepto ab eo iuramento de illum non offendendo". Cortiada quotes several references from Roman and canon law, and more than a dozen of authors to back up his argument. In $\S 13$ he continues, that in certain cases the cautio iuratoria could not be sufficient, but by the owner should be provided a stronger cautio ("recepta à domino maiori securitate"). For this opinion Cortiada quotes again several authors, like Farinacci, Diana, Barbosa. Cortiada does not say, if this stronger cautio was pignoraticia or fideiussoria; maybe both of them were possible. If the owner was not willing to provide some form of caution, he could be forced to sell the slave (§ 14); more detailed on this: Korzilius (2011).

${ }^{73}$ To mention the name of the PhD-supervisor (Stryk) and the PhD-candidate (Fuchs) in the case of early modern dissertations or theses corresponds to our knowledge on the specific form of academic cooperation between the two of them in the Early Modern Ages (Schubart-Fikentscher, 1970). I am grateful to prof. Susanne Lepsius, LMU Munich, for this information.

74 "Imo si à saevitia sibi metuat servus, cautio de non offendendo exigi poterit." This quotation is fascinating, because it reveals very well how the topical search for authorities by the jurists of the ius commune functioned. In the original context, the preoccupation of this part of the thesis of Fuchs, guided by Stryk, was with German serfs deserting from the fields because their fear of maltreatments by the vassals who held the land. Obviously, for our Portuguese lawyer the difference of the contexts was no problem at all! The same solution as to German serfs could apply to Portuguese slaves!

${ }^{75}$ The quotation of Brunnemann, though, is less pertinent, because Brunnemann does not mention the cautio. 
A very interesting turn could occur when slaves were imprisoned by their owners in a public prison. Such a massive demonstration of power, such an extreme deprivation of the factual, natural freedom of movement of the slave, the symbolic degradation to chattel, could suddenly turn against the owner, reduce perceptibly his powers, and even help to secure the slave's way to legal liberty. The means to reach this aim was a kind of freezing injunction (embargo), obtained by an attorney of the "slave", prohibiting the jailor (carcereiro) and prison staff to hand over the "slave" to his master, if the latter would not present the final sentence of a trial "in servitutem"

At Lisbon, slaves were sometimes imprisoned by their owners at the prison of Belém, near the harbor, to prepare to transport them overseas (mostly to Brazil). Especially in such cases, the lay brotherhoods hurried to get an injunction ${ }^{77}$. This became more frequent after the year of 1763, when the importation of Brazilian slaves to Portugal was prohibited in cases when Brazilian masters who had brought their slaves to Lisbon during a journey tried to re-export them ${ }^{78}$. Often such a plan failed -a new legal situation at the metropolis had turned this special kind of imported chattel into a free human being. Last-minute legal help reached slave Antonio José Joaquim in the year 1784 . He was already on board of a ship to be exported, when judicial officers reached him with the saving court order to have him deposited in prison ${ }^{79}$. The most favorable solution for the "slave" was to let him attend proceedings remaining (factually) free, upon posting a bond. To find a bailsman in such a case could mean the end of imprisonment to a slave, and preliminary freedom saw its most perfect flowering. Ownership saw itself deprived of many of its aspects as an all-embracing right to dominion. In extreme cases, it could be reduced to the economic interest incorporated in the slave. The bailment had to cover the "slave's" estimated market

\footnotetext{
${ }^{76}$ See, for example, ANTT FF FG maço J 2996, Irmandade de Nossa Senhora de Guadalupe ./. Francisco José Pereira (von 1818), fol. 12 v: "[O]s Suplicantes tem proposto em juizo a competente acção de liberdade contra o Suplicado, athe a decisão da mesma deve a dita sua Irman existir por Depozito na sobredita prizão em que se acha ou em caza decente e honesta, e temendo-se os Suplicantes dos subterfugios do Suplicado pertendem que Vossa Senhoria se sirva que seja a mesma embargada na prizão em que se acha a fim de ahi ficar em Depozito e da mesma não sahir sem ordem de Vossa Senhoria e decizão da dita cauza de liberdade [...]".

${ }^{77}$ As in the case of the slave Pedro (ANTT FF FG maço J 821, cx. 1864, Irmandade de Nossa Senhora do Rosario (Salvador da Mata) ./. Antonio José Basto (of the year1811)).

${ }^{78}$ Cf. ANTT FF FG maço J 1464, Irmandade de Nossa Senhora do Rosario dos Homens pretos (Salvador da Mata) ./. Manuel Coresma, of the year 1806), fol. 2.

${ }^{79}$ ANTT FF FG maço J 3181, Irmandade de Jesus Maria José (convento de Jesus) ./. Agostinho Rodriguez Alberto.
} 
value.

In some special situations, the positions seem somewhat changed in a paradoxical way, like in the question of sustentation. Whereas under normal conditions it was clear that ownership included the duty to nourish one's slave, owners sometimes refused this when their "property" turned rebellious and dared to claim freedom. Therefore, Rita Thereza had to claim to be maintained in her freedom against her owner, whose property suddenly had turned into a useless burden: without being able to exploit her labor, he would have to pay her a monthly sum, to be supported by the depositary. This sounded absurd to him. If Rita wanted to be sustained, such was his conclusion, she had to come back home and to continue her work. The fact that this incident went up to the highest court of the kingdom demonstrates, to what extent the opposing sides could harden. The Supreme Court decided in favor of Rita, but her owner still did not accept the verdict. He wanted the depository feed her, being the one who could use her laborforce. However, in accordance with dominant opinion, a depository was not allowed to use the deposited thing - and this meant he could not make a deposited slave work for him. But an owner did not admit defeat so easily. Did property not give him the right to auction the labor of his slave off publicly, at least during three days of the week, following the old rule "quidquid acquirit [the slave], domino acquirit"? As the court did not approve this proposal, the owner finally gave up. Unwilling to pay the sum to support the slave during the trial, he conceded liberty.

Summarizing this glance of aspects of the metropolitan freedom suit, we see the Portuguese alms with its procedural peculiarities inherited from Roman law, known by the Visigothic laws, and practiced during the late Middle Ages concerning enslaved Moors, in such a way as to be extended swiftly to black Africans, when they began to arrive in greater numbers at the peninsula during the fifteenth and sixteenth centuries. Slaves could get, and knew how to get access to courts; they were anything but passive objects. Their integration into social networks, especially in the form of lay brotherhoods, helped them to learn about ways and means to make use of the courts. Proceedings were complex and often lasted for months or even years. An important aspect is that there seems to have always been attorneys ready to assist "slaves". 


\section{The development in colonial courts}

Aside from blacks, Native Americans formed one first important group to demand liberty. We are much better informed about the respective situation in Spanish rather than the Portuguese American dominions. We know that the Audiencias, high courts in the capitals of the vice-kingdoms, dealt with thousands of freedom trials concerning Native Americans in the middle of the sixteenth century ${ }^{80}$. It is impressive, how a new social clash was expressed by long established legal semantics. The conflict between arrogated property rights and desire for freedom took the very same form as we saw in metropolitan freedom suits, even in procedural details. The Spanish colonizers did not want to cede possession of the litigating Natives during proceedings voluntarily, so the judges had to decide about this preliminary question, as described by Acevedo. The way the courts had to decide the question (favoring the interim liberty of Native Americans) shows how the global debates of public international law influenced even circumstantialities of procedural law ${ }^{81}$. Concerning indigenous Brazilians, the records I found, unfortunately are from the eighteenth century only, but they show the same questions still relevant. Like the Spanish crown, the Portuguese tried to limit indigenous slavery, above all by restricting the cases of just war. But taking into account the ideology of civilizing the savage, the labor policy and strategies of social discipline pursued by the metropolitan government, it was not difficult for the colonial settlers to achieve a kind of legal

\footnotetext{
${ }^{80}$ Lucena Salmoral (1982, p. 498) reports about 3.000 cases decided by the Audiencia of Mexico alone.

${ }^{81}$ Acevedo (1599, ad I. 8., tit. 9, lib. 3, p. 346 f.): One of the captive Indios, who existed as a slave, claimed to be freed, and he requested to be pronounced as such by the judge. In the meantime, when there does not exist any title about his unfree status, has he to be freed of the dominion of his owner, and of his servitude? (,Indorum qui in captivitate servitutis existebat, dicat \& asserat se liberum, \& pro tali à iudice pronuntiari petat, interim q[uod] non probatur titulus servitutis debeat à domino (sic!, in my opion dominio would be correct: of the dominion, of the power, because then the genitive domini, of the owner, would fit well) $d[$ omi]ni, \& eius servitute liberari?"). Follwing the rules of (later, Justinian) Roman law, he continues, it seems, that the "Indio" could not be set free, but would have to stay in the power of his alleged owner, because the latter should not be deprived of his possession. („Et videbatur dicendum quod non: quia dum in possessione servi adest, \& existit, d[omi]n[u]s no[n] debet ea possessione privari: \& quia secundu[m] tex. in I. circa ff. de probatio. tenetur probare se liberu[m], qui in possessione servitutis est. ") But in the case of Native Americans, the right decision, according to Acevedo, was the opposite one: The defendant should lose possession, because he bore the bruden of proof concerning the unfree status of the plaintiff („spoliatus d[omi]n[u]s illius servi Indi possessione, eius etiam lite durante, \& Indus in pristino statu libertatis consitutus, usque dum d[omi]n[u]s eius titulum servitutis legitim[u]m probaret"). By legal remedy the case came to the Real Audiencia $y$ Chancillería de Valladolid („pinciana“), which decided in the way reported by Acevedo.
} 
compromise, very favorable to their interests: Natives, which they could make work for them, were called "administrados" ("administrated"), and the relationship between the European and his "administrados", in the euphemistic language of the time, comprise a kind of guardianship, serving to educate the Natives in Christendom and European culture. In fact, the settlers used the new institution as nothing more than a fig-leave, must enable their treatment of their gentio like slaves, like chattel. That they did so gets evident especially by three practices: Natives appear like chattel in last wills, they were given as dowry, and they were sold (Monteiro, 1994, p. 147) transactions absolutely impossible with respect to free persons ${ }^{82}$.

However, was access to courts not extremely difficult for the Native Americans? Some of the first aspects that may come to our mind are language barriers. At a first level, we come across the highly specialized language of the legal professionals, the language of the books, still mostly in Latin. Local lawyers must have had access at least to some of them, mostly compilations of the essentials of ius commune, so called summulae. However, to whom were the Latin quotations in their written pleadings directed? Besides the members of the high courts, even in Portugal, only some larger towns had professionals as judges, the so-called juizes de fora. In smaller towns, the ordinary judge was taken from the senate of the municipal chamber, regularly its president, so he was a layman, and very often not able to understand the juridical Latin of his time, needing translations and explanations, provided by an assessor. In Brazil, the lack of professional judges was even greater. In addition to this first barrier, between professionals and nonprofessionals, or Latin and Portuguese, there is the barrier between Portuguese and Native language(s). The latter does not appear in the records. Nevertheless, that should not mislead us. The oral reality of colonial Brazil was completely different than the one of official written texts. The spoken language was the língua geral, in southeastern Brazil called paulista or austral, a Tupi-Guarani language (Rodrigues, 2002). Therefore, the Natives could formulate their claims in a language familiar to them, and only their legal assistants translated them to Portuguese in their writings. Another barrier was that of the legal complexities. However, here an institution already known in the metropolitan legal

\footnotetext{
${ }^{82}$ Here, where I dedicate attention to procedure, I may not enter into the details of that interesting discussion of material law.
} 
system helped: miserable and rural people (miserabiles and rustici) enjoyed certain procedural privileges, one of them being the right to get a curator ad litem to assist them. And the Native Americans were seen as an extreme case of poor peasants (Duve, 2008).

In the Capitania of São Paulo, in 1741, Bartholomeu, "descendant of the Native heathen" ("oriundo do gentio da terra"), stated to be de jure an administrado, but in fact was exploited worse than a slave by Domingos Bicudo. To get free from the latter, he entered court, and asked to be taken away from Bicudo and deposited ${ }^{83}$. Therefore, he went less far as the case quoted by Acevedo (1599) suggested ${ }^{84}$, but even so his deposit meant a noticeable loosening of Bicudo's grip. The very ambiguous function of a deposit gets clear when we compare Bartholomeu's case with the following one. In the village of Itanhaem, Capitania of São Paulo as well, in the year 1750, Antonio Vieira Callassa wanted to call Josepha de Oliveira, another "Native heathen", into slavery. To prepare proceedings, he requested that Josepha, who lived on her own, should be arrested and deposited. This act clearly demonstrates how he already tried to treat her like his slave. Depending on the direction of the claim, a deposit could (symbolically as well as practically) diminish the "owner's" rights or secure them. Nevertheless, Josepha's attorney did not hesitate to react: Because proceedings began while she in fact stayed in liberty, so his argumentation, she had to be kept free, and even without even being obliged to provide bail ${ }^{85}$. The attorney nearly literally followed the opinion we have learned from Acevedo (1599): because there was a presumption that all men were born free, and because slavery had to be considered as odious, the libellant bore the onus of proof, and therefore could not request to have the defendant, a descendant of the notoriously free Natives, deprived of her liberty preliminarily ${ }^{86}$. The judge had her arrested and deposited anyway. An

\footnotetext{
${ }^{83}$ AESP proc. civ. ord. 3316, proc. 818 , fol. 2, unfortunately without quoting any legal bases.

${ }^{84}$ That seems to be a general phenomenon of the freedom trials of Native Brazilians. They were much more treated like the described metropolitan factual slaves, in procedural practice.

${ }^{85}$ This latter obligation would only hit those, who struggled for freedom, living actually as slaves, thus the opposite case ("p[ar]a a Supp[lican]te dar fiança a sua pessoa devia estar na posse de cativa [...]", AESP, processos civeis, ord. 3412 proc. 3210 , fol. 4, without any legal quotations).

${ }^{86}$ Fol. 2 and 2 v: "[T] odos os homens por direito naçem livres e por t[ais] se devem ter todos, e a ser cativo, como co[usa] odioza a natureza p[ar]a hum se ter por tal, se deve pr[imeir]o provar com clareza e por esta razão não se pode mandar depozitar a Supp[lican]te por cativa, sem q[ue] prim[ei]ro probase a p[ar]te contr[ari]a q[ue] ella o era. Alem de q[ue] a Supp[lican]te descende do gentio da
} 
exceptio ${ }^{87}$ followed immediately, called "de manutenção" by the lawyer, who argued that the possessory situation had to be maintained during the suit ${ }^{88}$, the judge's contrary decision meant "espolio" ${ }^{89}$. Finally, Josepha won not only that preliminary question, but freedom as well. Her arrogated owner desisted, "in discharge of his soul", confessing her natural liberty as a Native American.

A very good example that sheds light on our question is the case of Joanna Pais and her children, also Native Americans, located at Santos ${ }^{90}$. They fled from the "administration", exercised by the widow Isabel Pais de Guerra, before entering court to claim freedom. The attorney of the widow immediately reacted with an exceptio spolii ${ }^{91}$. The safe custody of the claimants, in the meantime realized at the house of a third person, in the eyes of the widow did not go far enough. Her administrados should return to her power ("a Ré seja restituida à posse em que se achava de sua administração das Autoras"), if not, they should not be allowed to continue proceedings - an obvious attempt to transform "administration" into a kind of true property, because only chattel could be possessed, not a free person. Exactly for that latter reason, the attorney of the administradas consequently countered, the exception had no point ${ }^{92}$. Again, the local judge decided against the Native claimants. He decided that they had to return to her administradora. The law, argued Joanna's attorney, did not consider any tutor to have possession over the ward, and administration was more like tutelage than like ownership. However, things went

terra, como hé publico, e ninguem disto duvida hé tambem notorio q[ue] o tal gentio hé forro e liberto $[\ldots] . "$

${ }^{87}$ To get closer to the more recent language of US civil procedure, I suggest we maybe could translate this with objection.

${ }^{88}$ The scarce legal quotations are not so interesting, though. At fol. 61 the lawyer quotes Morais (1742, book VI, chapter VII, §§ 2-4), who says that no execution could have place without a final judgement. Thus the lawyer interprets the capture of the Natives as an illegal measure of execution. He also quotes Mendes de Castro (1696, book 3, chapter 21, § 38), with the statement "in dubio possessor praesumitur esse dominus". Here could have been quoted legal sources and opinions from more pertinent topoi.

${ }^{89}$ Fol $10 \mathrm{v}$, sic! The lawyer uses an intermediate form between the Latin spolium and the Portuguese esbulho.

${ }^{90}$ APESP AC 3459, 448, from the year 1730.

91 He quoted among other authors, Gabrieli (1608, 494-495 [Lib. V, conclusio II]), Menochio (1687, de retinend. possess. remed. III, §666, and de recuperand. possess. remed. XV).

92 "Dado porem, e não concedido que tivera a Administração nas AA exceytas, nunca em tempo Algum podia nellas, sendo livres, e libertas, adquirir Dominio, ou posse [...]." "Os Indios não se duvida que sejão livres, e S[e]n[ho]r[e]s de sua liberdade como qualquer outro homem logo tambem tem a posse della [...]." The lawyer quotes for example Pegas $\left(1682,2^{\text {nd }}\right.$ part, chapter XI, § 201): "[S]poliatus non dicitur, qui possidere non potuit, nec possidet". 
poorly. While still under protective custody, the claimants received a sentence ordering then to return to the widow. While they prepared their appeal, the depositary wanted to be released from responsability so they were transferred to the local jail, but could return to safe custody at a private household after a period. Finally, the appeal was successful. The upper court at São Paulo declared them not only free, but also free from administration. Maybe a certain trend becomes apparent - that lower, local courts tended not only to decide against the plain liberty of Native Americans in their final sentences, but already in the preliminary procedural rulings tended to equal them with slaves, thereby favoring the endeavor of the settlers to mould administration into true property.

More similar to the metropolitan situation was the procedural situation in cases involving slaves of African descent. The mandatum de manutenendo was applied $^{93}$ and Brazilian lawyers sometimes quoted Roman law directly, to justify its injunction ${ }^{94}$. The solution to concede the litigants three days off was not uncommon ${ }^{95}$, but like their metropolitan counterparts, Brazilian "slaves" asked to be taken away from their mistresses or masters and put into safe custody, when they feared to be maltreated ${ }^{96}$ or to be sold far away ${ }^{97}$. In a case from Mariana, in the year of 1763 , though, the lawyer tried to justify the measure as a development of the stilus ${ }^{98}$ of the Relação of Rio de Janeiro. In 1814, António José Carvalho Neto went to the court of

${ }^{93}$ Cf. one case of Ouro Preto of the year 1798 (Arquivo da Casa do Pilar (CP), Autos Cíveis, $1^{\circ}$ ofício, processo 221, 3580, fol. 2), the case of João from the year 1810 (Ouro Preto CP 1,188,2580 = AHCSM AC 2 [=2o ofício],[Códice]167,[Auto] 4001), or, from the same year, the case of Benedicta (AHCSM AC $1,413,9018)$. From Imperial Brazil cf. the cases of Apolonia from the year 1823 (APESP Autos Cíveis, 3422, 3387) or the case of Rosa (Rebola) from the year 1827 (Mariana AHCSM AC 1, 435, 9408, fol. 2), the case of João (Crioulo) of the year (1832), AHCSM AC 1, 405, 8851, the case of Eva Maria Ferreira from 1860 (AHCSM AC 2, 284, 6928), and the case of Ludivina (APEB SJ PC Est. 47, ex 1683 D 5, fol. 19).

${ }^{94}$ For example in the case AHCSM AC 2, 281, 6876 (from the year 1795), fol. 13 v: D. 41.2 .3 .10 (first clause: "Si servus, quem possidebam, pro libero se gerat, ut fecit Spartacus, et iudicium liberale pati paratus sit, non videbitur a domino possideri, cui se adversarium praeparat.").

${ }^{95}$ For example in some cases of the town AHCSM AC, like the one of slave Pedro of the year 1795 (AHCSM, AC 1, 392, 8572), or in $2^{\circ}$ oficio, 290, 7052 from 1795 as well, or in $1^{\circ}$ oficio $1,420,9137$ of the year 1809.

${ }^{96}$ Like the slave in a case of Ouro Preto of the year 1774 (of the local archive Casa do Pilar (CP), proc. civ. $1^{\circ}$ ofício, 149,1993$)$

97 As in AHCSM AC 2, 274, 6728 (of 1763): „[O] perigo he certo q[ue] pode a Sup[lica]da ser vindida")Various of this risks are put foreward in AHCSM AC 2, 239, 5978 (of the year 1748), fol. 2: The owner would threaten them with torments, or he could imprison them to impede their litigation, or transport them far away to make it difficult ("com algum tormento ou os prenda captivos e lhes impeda poderem tratar de termos de sua cauza por qualquer das refferidas formas ou trespassandoos para alguma parte por onde se lhe difficulta o progresso de tal cauza").

${ }^{98}$ AHCSM AC 2, 274, 6728, ibidem. 
Mariana to combat the safe custody obtained by two of his slaves who had left him as an attack against his seigniorial rights ${ }^{99}$. He did not get them back, and they were transferred to a custodian more acceptable to him than the first one. Even in the colonial context, some judges seem to have been reluctant to have a person, who lived as free, but was claimed as slave, simply caught. In 1807 a claimant wanted to have the pardo Domingos arrested, of whom he said to be his slave, immediately in the act of summons, but the judge only summoned the defendant ${ }^{100}$. However, especially coartados, slaves who had been able to negotiate with their owners to buy their freedom by installments, were often simply arrested, when their owners argued, that they did not pay the sum in time $e^{101}$. When a slave stayed in the power of a dominus, a cautio de non offendendo of the latter could be required, or, alternatively, the judge would threat the dominus with a fine ${ }^{102}$. Last but not least, the exceptio spolii was also well known in Brazil and applied in status trials ${ }^{103}$.

\section{Concluding remarks}

Maybe the strongest argument for the thesis of the lack of a rupture between (ancient and medieval) European and modern American slavery is the fact that the synopsis of the freedom trials of fifteenth century Valencia and of eighteenth century Minas Gerais did revealed nearly no difference. European erudite jurisprudence and colonial slavery were not worlds apart. The conservative (or rather reactionary) image

\footnotetext{
${ }^{99}$ AHCSM AC 2, 316, 7547.

${ }^{100}$ AHCSM AC 2, 326, 7776, fol. 2. The claimant requested: "[P]or q[ue] o d[it]o Escr[av]o logo q[ue] for citado se pode abzentar p[ar]a parte remota, do qual não haja mais noticia, requer o Sup[licant]e q[ue] no acto de citação seja o mesmo aprehendido por officiaes de justiça, até q[ue] dê fiança segura de não fugir e ainda aos jornais p[o]r q[ue] só assim pode litigar solto [...]." But the judge only ruled: "P[asse] M[an]dado simplesm[en]te p[ar]a a Citação."

101 For example in a case from Mariana, of the year 1811 (AHCSM AC, $2^{\circ}$ ofício, cod. 412, $n^{\circ} 11991$ ).

102 AHCSM AC 2, 262, 6460, do ano 1761 (mencionado também por Pinheiro, 2013, S. 204): „[Par]a não maltratar ao Sup[licant]e nem com elle entender té final S[e]n[ten]ça e sua Ex[ecuç]am debaixo da penna de mil oitavas de ouro [...] p[ar]a despezas da relação castigado como desobediente à justiça [...]." In the case, already mentioned, AHCSM AC 1, 420, 9137, fol. 81 (petição do 18 de novembro de 1811), the litigating "slaves" had to serve their owner during three days of the week, but in the case of hard or unjust punishments or maltreatment, the owner should loose these three days ("a pena de perder as mais dias da semana, ou prestação dos serviços dos Sup[licant]es").

${ }^{103}$ See the case of Isabel ("mulata") of the year 1740 (APESP 3327, 1163). The claimant claimed Isabel as his slave and had her imprisoned when starting a reivindicatio in servitutem against her. Her lawyer used the "exceyção de spolio", quoting Dig. 40.12.10, D. 41.2.3.10 and Justinian Code 7.16.14 (fol. 19 v); or the case of Josepha de Oliveira from the year 1750 (APESP AC 3412, 3210), whose lawyer also alleged "espolio" and formulated an "excepção".
} 
of slavery passed down by ancient legal semantics was a highly important factor in the formation of New World slave societies, and the centuries-old experience with slavery and slave law "in action" on the Iberian peninsula fostered a certain path-dependency. Due to the conservatism of the legal profession, voices that globally questioned the possibility to own human beings as property during medieval and early modern times were extremely rare. Colonial slavery was not shaped outside of courts, but largely inside of them. The state, in the form of colonial courts, did interfere into the masterslave-relations, and did influence them decisively. Therefore, the responsibility of the "long robe" in prevented the spread of colonial slavery, by offering cultivated accompaying semantics ("gepflegte Begleitsemantik" as Luhmann would say), should not be overestimated. The space for customary law to develop, to the contrary, was minimal. As the transatlantic comparison shows, we cannot characterize the colonial Brazilian legal system as a hybrid one. The organization of justice in the colony reflected much more the dream of an "immense Portugal", quite like in Chico Buarque de Holanda's ironic "Fado Tropical". We could even speak of a certain self-referentially of the legal system. As to the functioning of the colonial courts, once firmly established, they worked quite well and were not too much criticized by the metropolis. But there was definitely not a one-way-street of the mere reception of European slave law by colonial legal professionals. They also influenced the development of metropolitan law, as in the case of Antonio Vanguerve Cabral, who acted as a judge in Brazil, but whose Pratica judicial (Cabral, 1727) became a very important legal book in the second half of the eighteenth century, and saw a re-edition in Lisbon in $1842^{104}$. Finally, my findings reveal the strong continuity of the symbolic meaning of procedural incidents, by which the tensions between the principles of property and liberty expressed and discharged themselves, but also could be attenuated. In any case, by entering courts, slaves at all times opened a door that their masters and mistresses tried to keep closed.

\footnotetext{
${ }^{104}$ On the decentralized diffusion of legal production in the Spanish Empire see Duve (2012, p. 26-30), who rejects the idea of a mere reception of European legal thoughts in Latin America.
} 


\section{References}

ACEVEDO, A. de. 1599: Commentariorum luris Civilis in Hispaniae Regias Constitutiones, tres primos libros novae Recopilationis complectens. Tom. I, Madrid, ex officina loannis Gratiani apud viduam, 517 p.

AROUCA, A. Mendes. 1742. Adnotationes practicae. Lisbon, Dominici Gonçalves, 425 p. AZEVEDO, E. 2003. O Direito dos Esravos: lutas jurídicas e abolicionismo na Província de S. Paulo na segunda metade do século XIX. Campinas, SP, Doutorado, Unicamp, 224 p.

BARBOSA, A. 1712. Repertorium juris civili et canonici [...]. Lugdunum, Boudet, Declaustre, Deville et de la Roche, 250 p.

BASTIDE, R./FERNANDES, F. 1959. Brancos e negros em São Paulo, ensaio sociológico sôbre aspectos da fromação, manifestações atuais e efeitos do preconceito de côr na sociedade paulistana. São Paulo, Co. Ed. Nacional. 371 p.

BERGAD, L. W. 2007. The Comparative Histories of Slavery in Brazil, Cuba, and the United States. Cambridge, Cambridge University Press, 328 p.

BERTIN, E. 2004. Alforrias em São Paulo do século XIX:liberdade e dominação. São Paulo, Humanitas, 192 p.

BLACKBURN, R. 1996. The Making of New World Slavery. London/New York, Verso, $608 \mathrm{p.}$

BLUMENTHAL, D. 2009. Enemies and familiars: slavery and mastery in fifteenthcentury Valencia. Ithaca and London, Cornell University Press, 306 p.

BÖHMER, J. H. 1762. Exercitationes Ad Pandectas: in quibus praecipua Digestorum capita explicantur, antea sigillatim editae, nunc coniunctim secundum ordinem Pandectarum digestae, et indice instructae. Vol. 5, Hannover \& Göttingen, Schmid, 880 p.

BRUNNEMANN, J. 1683. Commentarius in leges pandectarum. Frankfurt (Oder), Schrey \& Meyer, $p$.

CABRAL, A. VANGUERVE. 1730. Practica judicial : muito util, e necessaria para os que principaõ os officios de julgar, \& advogar, \& para todos os que solicitaõ causas nos auditorios de hum, \& ouro foro. Lisbon, Antonio Simoens Ferreyra, 907 p.

CARDOSO, F. H. 1962: Capitalismo e escravidão no Brasil meridional; o negro na 
sociedade escravocrata no Rio Grande do Sul. São Paulo, Difusão Européia do Livro, $339 \mathrm{p.}$

CHALHOUB, S. 1990. Visões da liberdade: uma história das últimas décadas da escravidão na corte. São Paulo, Companhia das Letras, 288 p.

COING, H. 1985. Europäisches Privatrecht. vol. 1. Älteres Gemeines Recht (1500 bis 1800). Munich, Beck, 665 p.

CONRAD, R. E. 1994. Children of God's Fire: A Documentary History of Black Slavery in Brazil. Princeton, Princeton University Press, $515 \mathrm{p}$.

COOPER, F./HOLT, T. C./SCOTT, R. J. 2000. Beyond Slavery: Explorations of Race, Labor, and Citizenship in Postemancipation Societies. Chapel Hill, University of North Carolina Press, $216 \mathrm{p}$.

CORTIADA, M. de. 1665. Decisiones reverendi cancellarii, et sacri regii senatvs Cathaloniae. Pars Secunda. Barcelona, Forcada [iuxta Domum Regiam], 611 p.

COSTA, E. Viotti da. 2012. Da Senzala à Colônia. $5^{\text {th }}$ ed. São Paulo, Editora Unesp, 560 p.

CUNHA, M. Carneiro da. 1985. Sobre os silêncios da lei. Lei costumeira e positiva nas alforrias d escravos no Brasil do século XIX. Dados - Revista de Ciências Sociais, 28(1): 45-60.

DAL LAGO, E./KATSARI, C. 2008. The study of ancient and modern slave systems: setting an agenda for comparison. In: E. DAL LAGO/C. KATSARI, Slave Systems. Ancient and Modern. Cambridge, Cambridge University Press, p. 3-31.

DEGLER, C. N. 1971. Neither Black nor White: Slavery and Race Relations in Brazil and the United States. New York, Macmillan, 302 p.

DELACAMPAGNE, C. 2002. Une histoire de l'esclavage. De l'Antiquité à nos jours. Paris, Librairie Générale Française. 319 p.

DIN, G. C. 1999. Spaniards, Planters, and Slaves: The Spanish Regulation of Slavery in Louisiana, 1763-1803. College Station, Texas A\&M University Press, 376 p.

DIÓRIO, R. Romualdo. 2007. As marcas da liberdade: trajetórias sociais dos libertos em Mariana na segunda metade do século XVIII. São Paulo, SP, Mestrado, USP, 197 p.

DUVE, T. 2008. Sonderrecht in der frühen Neuzeit. Studien zum ius singulare und den privilegia miserabilium personarum, senum und indorum in Alter und Neuer Welt. Frankfurt (Main), Vittorio Klostermann, 358 p. 
DUVE, T. 2012. Von der Europäischen Rechtsgeschichte zu einer Rechtsgeschichte Europas in globalhistorischer Perspektive. Resarch Paper Series No. 2012-1. Frankfurt (Main), Max Planck Institute for European Legal History, 81 p.

EISENBERG, P. 1987. Ficando livre: as alforrias em Campinas no século XIX. Estudos Econômicos, 17 (2): 175-216.

ELKINS, S. M. 1959. Slavery, A Problem in American Institutional and Intellectual Life. Chicago, University of Chicago Press, 248 p.

ELSENHALS, H. 2007. Politische Ökonomie der Sklaverei vom 16.-18. Jahrhundert. In: M. Erdem Kabadayi/T. REICHARDT (org.), Unfreie Arbeit. Ökonomische und kulturgeschichtliche Perspektiven. Zurich/New York/Hildesheim, Olms, p. 242-259

FEBO, B. 1625. Decisiones Senatus Regni Lusitaniae. Vol. 2, Lisbon, ex officina Georgij Roderici, 728 p.

FELDBAUER, P./LIEDL. G./MORRISSEY, J. (org.). 2005. Mediterraner Kolonialismus. Expansion und Kulturaustausch im Mittelalter. Essen, Magnus, 307 p.

FIGUEIRA, P. de Alcântara /MENDES, C. M. M. 1977. Estudo preliminar. In: idem (org.): Jorge Benci (S.J.), Economia Cristã dos Senhores no Governo dos Escravos (livro brasileiro de 1700). São Paulo, Grijalbo, 224 p.

FONSECA, J. 2002. Escravos no Sul de Portugal. Lisbon, Vulgata, 261 p.

FRANCIOSI, G. 1961. Il processo di libertà in diritto romano. Naples, Jovene, 330 p.

FRAGOSO, J. B. 1737. Regimen reipublicae christianae, ex sacra theologia et ex utroque jure ad utroque forum coalescentis. Geneva, Bousquet \& Soc., 650 p. and Index.

FUENTESECA DEGENEFFE, M. 2006. La función procesal de los praedes litis et vindiciarum. Revue Internationale des droits de l'antiquité, 53: 237-264.

GABRIELI, A. 1608. Communes conclusiones. Venice, apud Nicolaum Misserinum, 779 p.

GAUDEMET, J. 1976. Les transferts du droit. Année Sociologique, 27, p. 29-59.

GENZMER, E. 1953. Das römische Recht als Mitgestalter gemeineuropäischer Kultur. In: D. SPYRO CONSTANTOPOULOS et al. (org.): Gegenwartsprobleme des internationalen Rechts und der Rechtsphilosophie. Festschrift für Rudolf Laun zu seinem 70. Geburtstag. Hamburg, Girardet \& Co. p. 499-535.

GENZMER, E. 1958. Das Römische Recht als Europäischer Kulturfaktor und der Plan einer neuen "allgemeinen Geschichte des Römischen Rechts im Mittelalter". In: Acta 
Congressus Madvigiani, vol. 1, Copenhagen, Ejnar Munksgaard, p. 267-279.

GENZMER, E. 1961. Einleitung. In: Ius Romanum Maedii Aevi. Pars I, 1 a-d. Milan, Giuffrè, p. 119-146.

GIARO, T. 2007. Alt- und Neueuropa, Rezeptionen und Transfers. In: T. GIARO (org.), Modernisierung durch Transfer zwischen den Weltkriegen. Frankfurt (Main), Klostermann, p. 273-310.

GOECKE, F. 1858. De exceptione spolii. Berlin, Schade, 107 p.

GONÇALVES, A. L. 2000. As margens da liberdade:Estudo sobre a prática de alforrias em Minas colonial e provincial. Belo Horizonte, Fino Traço, 288 p.

GONÇALVES, J. C. 2006. Justiça e direitos costumeiros: apelos judiciais de escravos, forros e livres em Minas Gerais (1716-1815). Belo Horizonte, MG, Mestrado, 187 p.

GRINBERG, K. 1994. Liberata: a lei da ambiguidade. As ações de liberdade da Corte de Apelação do Rio de Janeiro no século XIX. Rio de Janeiro, Relume Dumará, 122 p.

GURGEL, A. E. 2004. A Lei de 7 de novembro de 1831 e as ações cíveis de liberdade na Cidade de Valença (1870-1888). Rio de Janeiro, RJ, Mestrado, UFRJ, 79 p.

INDRA, M. 2011. Status quaestio. Studien zum Freiheitsprozess im klassischen römischen Recht. Berlin, Duncker \& Humblot, 314 p.

INGERSOLL, T. N. 1999. Mammon and Manon in Early New Orleans: The First Slave Society in the Deep South, 1718-1819. Knoxville, University of Tennessee Press, 520 p. KASER, M./HACKL, K. 1996. Das römische Zivilprozessrecht. $2^{\text {nd }}$ ed, München, Beck, $712 \mathrm{p}$.

KASER, M./KNÜTEL, R./LOHSSE, S. 2017. Römisches Privatrecht. Ein Studienbuch. $21^{\text {th }}$ ed., Munich, Beck, $518 \mathrm{p}$.

KLEIN, H. S. 1967. Slavery in the Americas: A Comparative Study of Virginia and Cuba. Chicago, University of Chicago Press, $270 \mathrm{p}$.

KORZILIUS, S. 2011. „Ob saevitiam cogi dominum vendere, ut hic resolvitur" römisches Recht in Statusprozessen aus Portugal (und Brasilien) am Beispiel der zivilrechtlichen Folge der Sklavenmisshandlung. In: E. HERMANN-OTTO, coop.: A. TREFZ and M. SIMONIS, (org.), Sklaverei und Zwangsarbeit zwischen Akzeptanz und Widerstand. Hildesheim/Zurich \& New York, Olms, p. 75-93.

LANDERS, J. 1999. Black Society in Spanish Florida. Urbana and Chicago, University of Illinois Press, $416 \mathrm{p}$. 
LITEWSKI, W. 1999. Der römisch-kanonische Zivilprozess nach den älteren ordines iuridicarii. 2 vols., Kraków, Wydawnictwo Uniwersytetu Jagiellońskiego, 652 p.

LOBÃO, M. de Almeida e Sousa de. 1867. Tratado encyclopedico compendiario, pratico e systematico dos interdictos e remedios possessorios geraes e especiaes conforme o direito romano, patrio e uso das nações. Lisbon, Imprensa Nacional, 223 p.

LUCENA SALMORAL, M. 1982. El Descubrimiento y la fundación de los reinos ultramarinos: Hasta fines del siglo XVI. Madrid, Rialp, 847 p.

MACEDO, A. de Sousa de. 1699. Decisiones supremi senatus justitiae Lusitaniae, et supremi consilii fisci, ac patrimonii regis: Cum gravissimis collegis decretae ac in lucem editae. Lisbon, Bernardo da Costa de Carvalho, 318 p.

MARTÍNS CASARES, A. 1995. De la esclavitud a la libertad: las voces de moriscas y moriscos en la Granada del siglo XVI. Sharq Al-Andalus 12:197-212.

MENDES de CASTRO, E. 1696. Practica lusitana. Vol. I, Coimbra, Ferreyra, 276 p.

MENOCHIO, G. 1687. De adipiscenda, retinenda, et recuparenda possessione doctissima comentaria. Geneva, De Tournes, 598 p.

METZGER, E. 2013. An Outline of Roman Civil Procedure. Roman Legal Tradition 9: 130.

MONTEIRO, J. M. 1994. Negros da terra. Índios e bandeirantes nas origens de São Paulo. São Paulo, Companhia das Letras, 300 p.

MORAIS [MORAES], S. GOMES de. 1742. Tractus de executionibus instrumentorum \& sententiarum. Vol. 3. Coimbra, Ferreyra, $396+47$ p.

NEHLSEN, H. 1972. Sklavenrecht zwischen Antike und Mittelalter. Germanisches und Römisches Recht in den germanischen Rechtsaufzeichnungen. I. Ostgoten, Westgoten, Franken, Langobarden. Göttingen/Frankfurt (Main)/Zurich, Musterschmidt, 432 p.

NEHLSEN-VON STRYK, K. 1991. Der römisch-kanonische Zivilprozeß in der gesellschaftlichen Realität des 13. Jahrhunderts. In: M. STOLLEIS et al. (orgs.), Die Bedeutung der Wörter. Studien zur europäischen Rechtsgeschichte. Festschrift für Sten Gagnér zum 70. Geburtstag, München, Beck, p. 313-326.

NICOLAU, M. 1933. Causa Liberalis. Paris, Sirey, 332 p.

NISHIDO, M. 1993. Manumission and Ethnicity in Urban Slavery: Salvador, Brazil, 18081888. Hispanic American Historical Review, 73: 361-391.

NÖRR, K. W. 2012. Romanisch-kanonisches Prozessrecht. Erkenntnisverfahren erster 
Instanz in civilibus. Berlin/Heidelberg, Springer, $241 \mathrm{p}$.

OSTERHAMMEL, J. 2009. Sklaverei und die Zivilisation des Westens. $2^{\text {nd }}$ ed., Munich, Carl Friedrich von Siemens Stiftung, 73 p.

OTÁLORA, J. Arce de: Summa nobilitatis hispanicae, et immunitatis regiorum tributorum, causas, ius, ordinem, iudicium, \& excusationem breviter complectens [...]. Salamanca, Moreni, 358 p.

PAIVA, E. França. 1995. Escravos e libertos nas Minas Gerais do século XVIII; estratégias de resistência através dos testamentos. São Paulo, Annablume, 242 p.

PEGAS, E. ALVAREZ. 1682. Resolutiones forenses practicabiles. Lisbon, Deslandes, $1306 \mathrm{p}$.

PEIXOTO, L. Rossi de Rosis. 2013. Um estudo histórico do processo civil com vistas à efetivação do direito material. Londrina (PR), Mestrado, UEL, 97 p.

PINHEIRO, F. A. Domingos. 2013. Em defesa da liberdade: libertos e livres de cor nos tribunais do Antigo Regime português (Mariana e Lisboa, 1720-1819). Campinas, SP, Doutorado, Unicamp, $311 \mathrm{p}$.

POSTIO, L. 1646. Tractatus mandati de manutenendo, sive possessorii summariissimi, Vol. 1: Observationes. Geneva, Gamonet, 388 p.

RODRIGUES, A. Dall'Igna Rodrigues. 2002. Línguas brasileiras: para o conhecimento das línguas indígenas. $4^{\text {th }}$ ed., São Paulo, Ed. Loyola, 134 p.

RUFFINI, F. 1889. L'actio spolii. Studio storico-giuridico. Turin, Fratelli Bocca, 463 p.

SACCO, R. 1991. Legal Formants: A Dynamic Approach to Comparative Law. The American Journal of Comparative Law, 39 (1 \& 2), 1-34 \& 343-401.

SARMIENTO de MENDOZA, F. 1616. Interpretationes selectae. Antwerp: Keerberg, 732 p.

SAVELLI, M. A. 1748. Summa diversorum tractatum, vol. I. Venice, Balleoni, 608 p.

SCHIAVONE, A. 2002. La storia spezzata. Roma antica e Occidente morderno. Roma and Bari, Laterza \& Figli, 262 p.

SCHUBART-FIKENTSCHER, G. 1970. Untersuchungen zur Autorschaft von Dissertationen im Zeitalter der Aufklärung. [Sitzungsberichte der Sächsischen Akademie der Wissenschaften zu Leipzig. Philologisch-historische Klasse. Band 114, Heft 5.]. Berlin, Akademie-Verlag, 135 p.

SCIORTINO, S. 2010. Studi sulle liti di libertà nel diritto romano. Turin, Giappichelli, 367 
p.

SCOTT, R. J. 2005. Degrees of Freedom: Louisiana and Cuba after Slavery. Cambridge MA, Harvard University Press, 384 p.

SELLERT, W. 1998. Zur Rezeption des römischen und kanonischen Rechts in Deutschland von den Anfängen bis zum Beginn der Neuzeit. Überblick, Diskussionsstand und Ergebnisse. In: H. BOOCKMANN et al. (orgs.). Recht und Verfassung im Übergang vom Mittelalter zur Neuzeit, $1^{\text {st }}$ part. Göttingen, Vandenhoeck \& Ruprecht, p. 115-166.

SILVA, R. T. Caires. 2007. Caminhos e descaminhos da abolição. Escravos, senhores e direitos nas útlimas décadas da escravidão (Bahia, 1850-1888). Curitiba, PR, Doutorado, UFPR, 320 p.

STRYK, S. (praes.)/FUCHS, E. (resp.). 1698. De agris desertis. Von Wüsten Hufen. In: S. STRYK (org.), Dissertationum juridicarum volumen novum [=vol. 4] ex jure publico, privato, feudali et statutario [...]. Leipzig/Hannover, Banckmann/Förster, Disp.II, 72 p.

TANNENBAUM, F. 1946. Slave and Citizen. The Negro in the Americas. New York, Alfred A. Knopf, 128 p.

TRUSEN, W. 1962. Anfänge des gelehrten Rechts in Deutschland. Ein Beitrag zur Geschichte der Frührezeption. Wiesbaden, Steiner, 279 p.

VERLINDEN, C. 1955. L'esclavage dans l'Europe médiévale. Vol. I. Péninsule IbériqueFrance. Bruges, Faculteit van de Letteren en Wijsbegeerte of the University of Ghent, $930 \mathrm{p.}$

WATSON, A. 1989. Slave Law in the Americas. Athens/London, University of Georgia Press, 200 p.

WIEACKER, F. 1967. Privatrechtsgeschichte der Neuzeit unter besonderer Berücksichtigung der detuschen Entwicklung. $2^{\text {nd }}$ ed., Göttingen, Vandenhoeck \& Ruprecht, $659 \mathrm{p}$.

WILLOWEIT, D. 2002. Rezeptionen. In: K. LÜDERSSEN (org.), Die Durchsetzung des öffentlichen Strafanspruchs. Köln/Weimar/Wien, Böhlau, p. 153-162.

Artigo recebido em 15 de outubro de 2017 e aprovado em 18 de janeiro de 2018. 